\title{
Four different Phytophthora species that are able to infect Scots pine seedlings in laboratory conditions
}

\author{
Miłosz Tkaczyk ${ }^{1} \bowtie$, Katarzyna Sikora ${ }^{1}$, Justyna A. Nowakowska², Ewa Aniśko ${ }^{3}$, \\ Tomasz Oszako ${ }^{4}$, Lassaâd Belbahri ${ }^{5}$, Ivan Milenković ${ }^{6}$ \\ ${ }^{1}$ Forest Research Institute, Department of Forest Protection, Braci Leśnej 3, 05-090 Raszyn, Poland, \\ e-mail: M.Tkaczyk@ibles.waw.pl \\ ${ }^{2}$ Forest Research Institute, Laboratory of Molecular Biology, Braci Leśnej 3, 05-090 Raszyn, Poland \\ ${ }^{3}$ Forest Research Institute, Department of Silviculture and Genetics of Forest Trees, Braci Leśnej 3, 05-090 Raszyn, \\ Poland \\ ${ }^{4}$ Technical University in Białystok, Forest Faculty, Piłsudskiego 8, 17-200 Hajnówka, Poland \\ ${ }^{5}$ University of Neuchatel, Laboratory of Soil Biology, Rue Emile Argand 11, 2009 Neuchâtel, Switzerland \\ ${ }^{6}$ Institute of Forestry Belgrade, Kneza Višeslava 3, 11030 Belgrade, Serbia
}

\section{Abstract}

To investigate susceptibility of young Scots pine seedlings to four Phytophthora species: Phytophthora cactorum, Phytophthora cambivora, Phytophthora plurivora and Phytophthora pini; seven-day-old seedlings of Scots pine (15 seedlings per experiment) were infected using agar plugs of the respective species. Control group also consisted of 15 seedlings and was inoculated with sterile agar plugs. Results unambiguously show that after 4.5 days, all seedlings show clear signs of infection and display severe symptoms of tissue damage and necrosis. Moreover, three and two seedlings in the $P$. cactorum and P. cambivora infected seedlings groups, respectively, collapsed. The length of largest necrosis measured $13.4 \pm 3.90 \mathrm{~mm}$ and was caused by $P$. cactorum. To rule out any putative contamination or infection by secondary pathogens, re-isolations of pathogens from infection sites were performed and were positive in $100 \%$ of plated pieces of infected seedlings. All re-isolations were, however, negative in the case of the control group. Detailed microscopic analyses of infected tissues of young seedlings confirmed the presence of numerous Phytophthora species inside and on the surface of infected seedlings. Therefore, our results suggest Phytophthora spp. and mainly P. cactorum and P. cambivora as aggressive pathogens of Scots pine seedlings and highlight a putative involvement of these species in the damping off of young Scots pine seedlings frequently observed in forest nurseries.

\section{KeY WORDS}

pathogenicity, Pinus sylvestris, Phytophthora cambivora, Phytophthora cactorum, light microscopy 


\section{INTRODUCTION}

Scots pine (Pinus sylvestris L.) is the most common woody species in Polish forests and is present in around $58.8 \%$ of total forest stands managed by State Forests in Poland (Milewski 2015). Unfortunately, Scots pine is susceptible to several pathogenic organisms in natural stands, planted forests and nurseries, including Heterobasidion annosum (Fr.) Bref. (Sierota 1996; Małecka and Sierota 2003). Different needle diseases, such as red band needle blight, caused by the fungus Dothistroma septosporum (Dorog.) Morelet also play an important role in the decline of this relevant tree species (Mańka 1998; EFSA 2013).

Phytophthora species are fungal-like organisms that nest within the SAR supergroup (Lara and Belbahri, 2011; Adl et al. 2012). Till now, more than 140 species and Phytophthora taxa are known (Abad 2014). These species are able to infect different tissues (fine roots, bark, stems, leaves and shoots) on different host species in nurseries, ornamental plantings and forest stands (Erwin and Ribeiro 1996; Pérez-Sierra and Jung 2013; Jung et al. 2013). Previously, several Phytophthora spp. have been recorded as pathogens of different conifer species, including Phytophthora cactorum (Leb. and Cohn) Schröeter (Hudler 2013), Phytophthora cambivora (Petri) Buisman (Vannini and Vettraino 2011), Phytophthora lateralis Tucker and Milbrath (Hansen 2011), Phytophthora pini Leonian (Hong et al. 2011), Phytophthora pinifolia (Duran et al. 2008; Hansen 2012), Phytophthora plurivora Jung and Burgess (Jung and Burgess 2009) and Phytophthora citrophthora (R.E. Smith et E.H. Smith) Leonian (Oszako and Orlikowski 2004).

Occurrence of these pathogenic Phytophthora spp. in nurseries and their subsequent introduction into seminatural and natural ecosystems is the main driver of their dispersal and causes huge damage to forest ecosystems (Moralejo et al. 2009; Jung et al. 2015). In Poland, several species of Phytophthora were recorded in forest nurseries, including Phytophthora citricola Sawada on ash (Orlikowski et al. 2004), Phytophthora cinnamomi Rands on pedunculate oak (Oszako and Orlikowski 2005), P. plurivora on European beech and silver fir (Orlikowki et al. 2004; Stępniewska 2005), P. cactorum on European beech (Stępniewska 2003) and Phytophthora gonapodyides on a wide range of hosts (Oszako et al. 2007). Phytophthora spp. were also previously re- corded on Scots pine in forest and ornamental nurseries in Poland, and the presence of $P$. cinnamomi (Duda et al. 2004), P. cactorum, P. citrophthora and P. plurivora (Orlikowski et al. 2012) was confirmed.

Owing to widespread and importance of Scots pine in Polish forests, our main goal was to determine whether the Phytophthora species can threaten Scots pine plants grown in nurseries and in young stands. Pathogenicity test with four selected Phytophthora species were, therefore, conducted, to determine the susceptibility levels of the Scots pine seedlings with selected species. Results and implications of the study are discussed in this paper.

\section{Material AND methods}

\section{Phytophthora species and isolates used in the experiment}

Isolates of Phytophthora species used in the colonisation test were obtained from the Forest Research InstituteIBL Phytophthora culture collection. All isolates originated from different declining forest tree hosts. They were all morphologically identified, with molecular confirmation of morphological findings. Four different Phytophthora species were used in this experiment (Tab. 1).

Table 1. Description of isolates used in the experiment

\begin{tabular}{|l|l|c|c|}
\hline \multicolumn{1}{|c|}{ Species } & \multicolumn{1}{|c|}{ Host } & $\begin{array}{c}\text { Collection } \\
\text { number }\end{array}$ & GenBank \\
\hline P. cactorum & $\begin{array}{l}\text { Acer pseudo- } \\
\text { platanus }\end{array}$ & IBL325 & JX276090 \\
\hline P. cambivora & Fagus sylvatica & IBL340 & JX276088 \\
\hline P. pini & Poplar clone I214 & IBL482 & KF234656 \\
\hline P. plurivora & Quercus robur & IBL213 & JX276023 \\
\hline
\end{tabular}

\section{Pathogenicity tests}

In the different pathogenicity tests, non-stratified seeds of Scots pine were used (Zwoleń provenience). Seeds were incubated at $25^{\circ} \mathrm{C}$ under light for $24 \mathrm{~h}$ in glass chambers moisturised with sterile cotton wetted with sterile distilled water (Załęski et al. 1998). Phytophthora species used in the assay were transferred onto V8A media, prepared with $800 \mathrm{ml} \cdot \mathrm{L}^{-1}$ distilled water, $200 \mathrm{ml} \cdot \mathrm{L}^{-1}$ V8 juice (Tymbark, Poland), $18 \mathrm{~g} \cdot \mathrm{L}^{-1}$ agar-agar (BTL, Poland) and $3 \mathrm{~g} \cdot \mathrm{L}^{-1}$ of $\mathrm{CaCO}_{3}$. The inoculum of Phy- 
tophthora spp. was recovered from the growing edges of 3-4 days old colonies incubated at $22-25^{\circ} \mathrm{C}$ in the dark (Orlikowski et al. 2004; Milenković et al. 2012). Agar plugs with mycelium $(\sim 1 \times 1 \mathrm{~cm}$ in size) were placed in sterilised, $90-\mathrm{mm}$ glass Petri dishes containing sterile filter paper. Tips of seven-day-old Scots pine seedlings with a radicle length of $15-20 \mathrm{~mm}$ were placed on the top of agar plugs with mycelium in Petri dishes. The design of the experiment was completely randomised with a total of five replicates. For each replication, seedlings were used in individual Petri dishes ( $\mathrm{N}=15$ seedlings per group). Control group also consisted of 15 seedlings and was placed on the sterile agar plugs.

Filter paper in the dishes was moisturised with $5 \mathrm{~mL}$ of sterile distilled water, and dishes were incubated under daylight at approximately $20-22^{\circ} \mathrm{C}$. Dishes were monitored for every $8 \mathrm{~h}$ until the first seedlings collapsed, and measurements of the total lengths of seedlings and the necrosis length were performed.

To re-isolate the Phytophthora spp. from declining tissues, small necrotic parts of the seedlings $(0.1-0.2 \mathrm{~mm}$ in size) were cut using sterile razor blade and plated on selective media (V8A-PARPNH), prepared according to Jung et al. (1996). Tissue fragments from control group were also plated onto V8A-PARPNH media. Observations were made under light microscope ZEISS Axioskop 2, equipped with Nikon Ds-fil camera, and NIS Elements AR4 ${ }^{\circledR}$ software.

\section{Statistical analyses}

Data from the pathogenicity test were subjected to Kruskal-Wallis nonparametric test. The mean values of total length of plant, length of necrosis and percentage of necrosis were compared between the experimental groups using R software (PMCMR library).

\section{Results}

\section{Pathogenicity tests and necrosis lengths}

After 4.5 days of incubation when the first seedlings collapsed, measurements of necrosis lengths as well as total length of the seedlings were performed and are presented in Table 2. Three and two seedlings, respectively, from the P. cactorum and P. cambivora groups collapsed. Photos of necrotic lesions of these seedlings are presented in Figure 1.
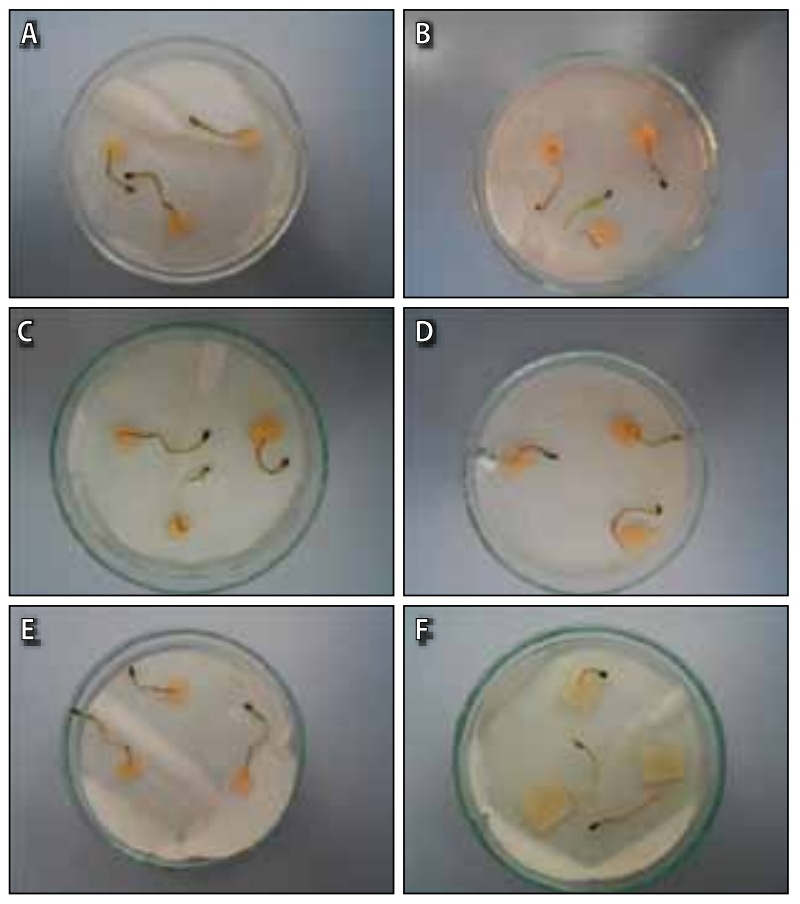

Figure 1. Necrotic lesions on seedlings caused by different Phytophthora species: A - P. cambivora; B - P. plurivora; $\mathrm{C}-$ P. pini; D-E - P. cactorum; $\mathrm{F}$ - control

Table 2. Pathogenicity of the different Phytophthora species inoculated on seedlings of Scots pine

\begin{tabular}{|c|c|c|c|c|c|}
\hline \multirow[t]{2}{*}{ Species } & \multirow{2}{*}{$\begin{array}{c}\text { Number per experi- } \\
\text { mental group }\end{array}$} & \multirow{2}{*}{$\begin{array}{c}\text { Number of } \\
\text { collapsed seedlings }\end{array}$} & $\begin{array}{l}\text { Total length of } \\
\text { seedlings }\end{array}$ & Necrosis length & \multirow{2}{*}{$\begin{array}{c}\begin{array}{c}\text { Percentage } \\
\text { of necrotic length }\end{array} \\
\% \pm \mathrm{SD}\end{array}$} \\
\hline & & & \multicolumn{2}{|c|}{ mean $\pm \mathrm{SD}(\mathrm{mm})$} & \\
\hline Control & \multirow{5}{*}{15} & 0 & $43.06 \pm 10.51$ & 0 & 0 \\
\hline P. cactorum & & 3 & $37.00 \pm 4.14$ & $13.4 \pm 3.90$ & $37.49 \pm 14.15$ \\
\hline P. cambivora & & 2 & $36.73 \pm 9.67$ & $11.80 \pm 3.36$ & $32.81 \pm 7.59$ \\
\hline P. pini & & 0 & $43.46 \pm 12.87$ & $10.93 \pm 3.89$ & $27.09 \pm 10.85$ \\
\hline P. plurivora & & 0 & $39.53 \pm 10.44$ & $9.66 \pm 3.10$ & $26.41 \pm 10.59$ \\
\hline
\end{tabular}


Re-isolations were successful in $100 \%$ of plated necrotic parts of the seedlings onto selective agar media, whilst the parts from control group showed no growth and were negative for the presence of any pathogenic or saprotrophic organisms.

Nonparametric test was applied to check statistical significance of seedling lengths between the tested experimental groups. No statistically significant difference between the tested experimental groups could be observed $(p=0.337)$. However, necrosis length between the different experimental groups was statistically significant $(p=0.000)$. To determine which experimental groups were statistically different, the post hoc test was applied. Results clearly suggest statistical support for the difference between each Phytophthorainfected experimental and the control group. We could also provide statistical support for $P$. cactorum causing the largest necrosis length than all the other tested species (Fig. 2).

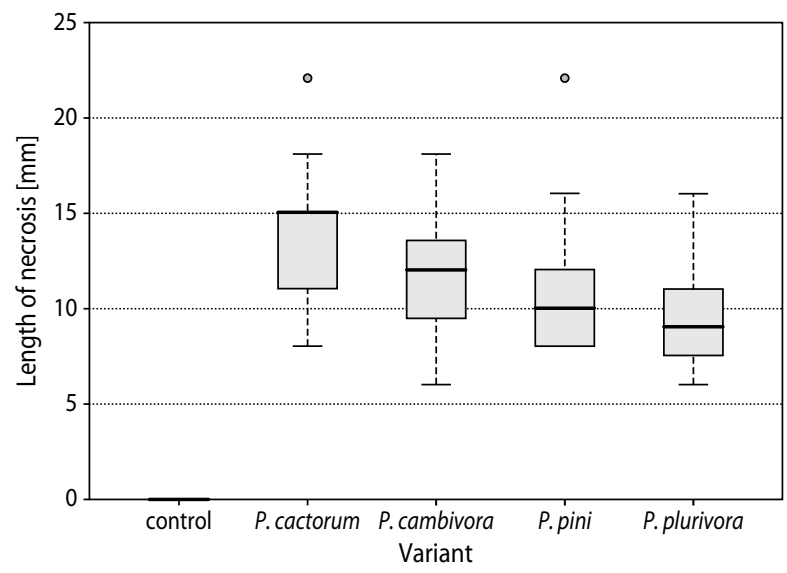

Figure 2. Necrosis lengths observed on Scots pine seedlings infected with the different Phytophthora spp.

Percentage of necrosis length (estimated as the percentage of observed necrosis per total plant length) was calculated for the control and experimental groups. The comparison between percentage of necrosis length amongst the different groups showed statistically significant difference between control and experimental groups infected by the respective Phytophthora species $(p=0.000)$. Between variants in which the Phytophthora was tested, no statistically significant difference was observed. The highest value was recorded for the P. cactorum experimental group (Fig. 3).

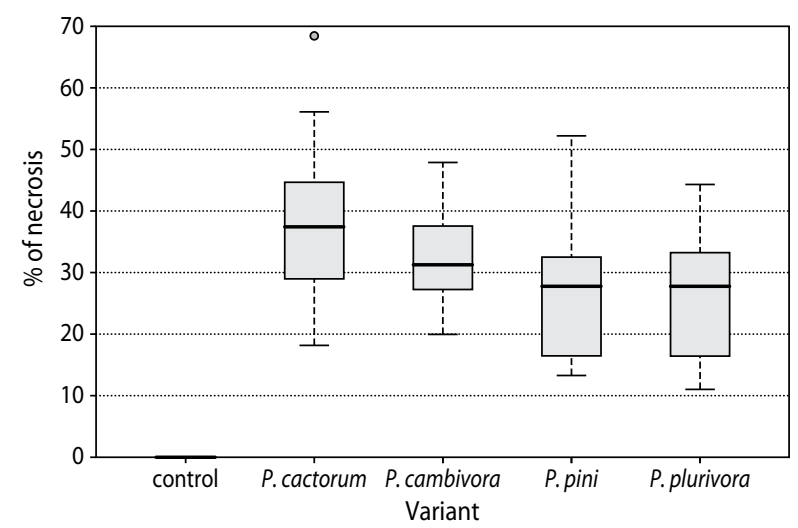

Figure 3. Percentages of necrosis length across the different control and Phytophthora infected experimental groups

\section{Microscopic analyses}

All tested Phytophthora spp. in the time course of this experiment were able to colonise the tissues of young seedlings. Observation under light microscope showed the presence of numerous Phytophthora structures in the tissues of all the infected seedlings. In most of the cases solely, oogonia with oospores were recorded (Fig. 4), whilst in some other cases, both oogonia and sporangia were recorded (Fig. 4C, D and H). No Phytophthora structures were recorded in the control group in which the tissues remained healthy.

\section{Discussion}

Results obtained in the course of this study unambiguously document the ability of the four tested Phytophthora species to infect the young Scots pine seedlings. Severe seedlings symptoms and damage to infected tissues reflected by necrosis length that differ in size between the respective pathogens were observed. The most aggressive species in our experimental conditions was $P$. cactorum, according to all monitored parameters. This homothallic species with papillate sporangia was one of the first described species from the Phytophthora genus (Erwin and Ribeiro 1996). This pathogen is causing damages on a wide range of hosts worldwide in nurseries, forest stands, ornamental and amenity plantings (Erwin and Ribeiro 1996), including Scots pine (Hudler 2013). This species belongs to Phytophthora Clade 1 (Martin et al. 2014) and is able to operate dif- 
ferent hybridisation events (Érsek and Man in 't Veld 2013), giving rise to more aggressive and destructive pathogens (Man in’t Veld et al. 2007, 2012).
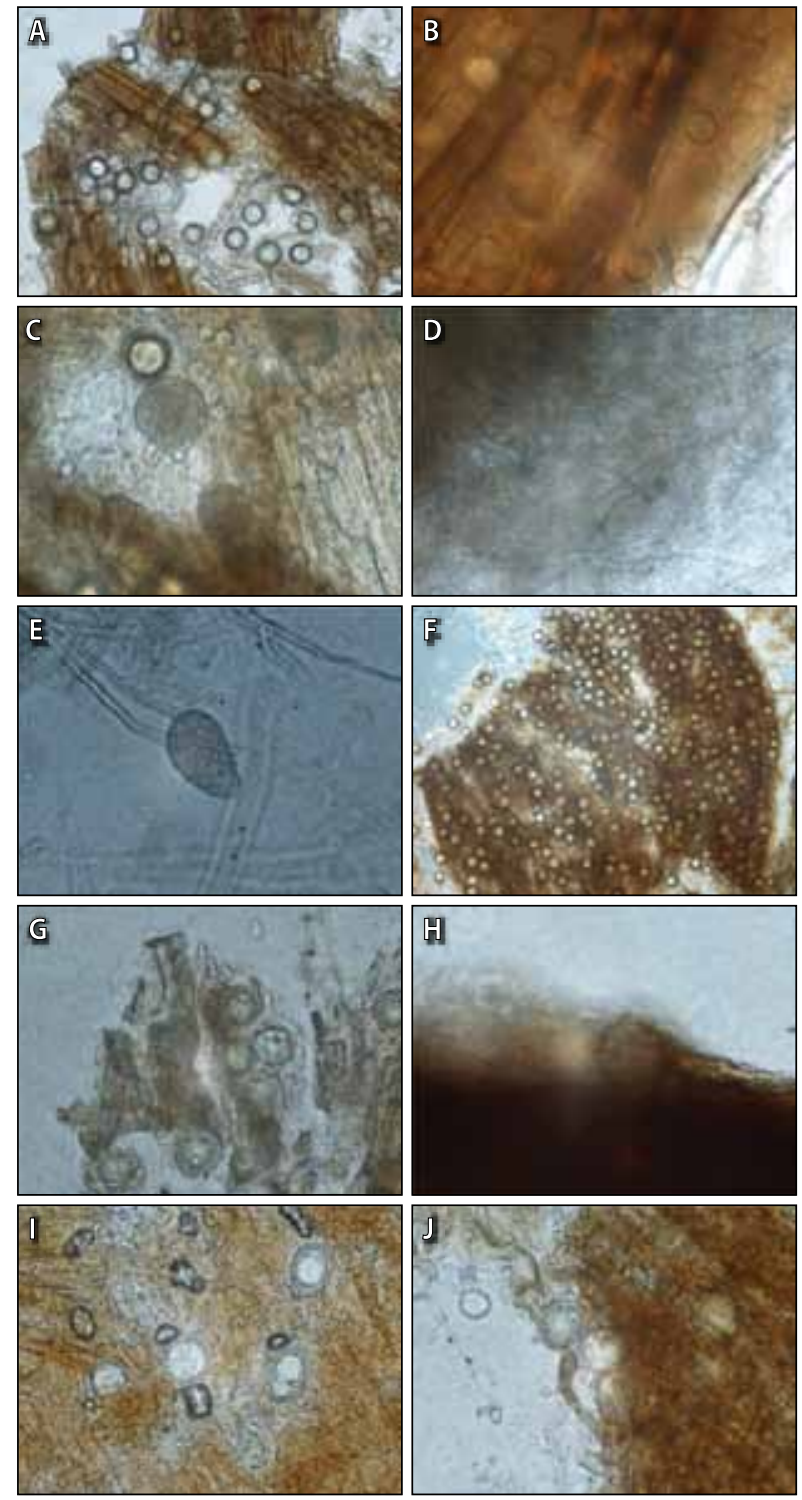

Figure 4. Microscopic analyses of the necrotic length of Scots pine tissue

P. cactorum: A - numerous oogonia in the necrotic tissue at $\times 200$ magnification, $\mathrm{B}-$ oogonia in the tissue at $\times 400$ magnification, $\mathrm{C}-$ oogonia and papillate sporangia in the broken necrotic tissue at $\times 400$ magnification; $\boldsymbol{P}$. cambivora: D - hypha and young sporangia at $\times 200$ magnification, $\mathrm{E}$ - non-papillate, mature sporangia on the surface of infected seedlings at $\times 400$ magnification; $\boldsymbol{P}$. pini: $\mathrm{F}$ - numerous oogonia in the tissue at $\times 100$ magnification, $\mathrm{G}-$ oogonia in the broken necrotic tissue at $\times 400$ magnification, $\mathrm{H}-$ semi-papillate sporangia on the surface of necrotic tissue; P. plurivora: I and J-oogonia in the necrotic tissue.
The second more aggressive species in our experiment was P. cambivora. This is heterothallic species with non-papillate sporangia, easily recognised by ornamented oogonia and two cells antheridia. It is known worldwide as the causative agent of ink disease (Erwin and Ribeiro 1996).

The third aggressive species in this experiment is $P$. plurivora, one of the most widespread species in different ecosystems worldwide. This species was previously lumped in the $P$. citricola Sawada species complex but was recognised as a new species in the study of Jung and Burgess (2009). It can parasitise a wide range of plant hosts, causing different damages and thriving in different ecological niches (Jung and Burgess 2009).

All listed species were often previously reported from different Polish nurseries (Duda et al. 2004; Orlikowski et al. 2012). However, there is no much data concerning $P$. pini. P. pini was described for the first time by Leonian (1925) and resurrected by Hong et al. (2011) as a part of the P. citricola complex. According to these authors, this species is a pathogen of at least seven genera in Europe and North America and many past damages that were assigned to P. citricola were actually caused by this species and $P$. plurivora. In Europe, this species was recorded in Finnish nurseries (Rytkönen 2011) and in poplar plantations in Serbia (Milenković I., unpublished data).

During the analyses of necrotic tissue using light microscopy, numerous oogonia were recorded inside and on the surface of the tissue of infected seedlings. Hyphae and sporangia of tested Phytophthora species were also recorded in congruence with multicyclic nature of these pathogenic organisms (Erwin and Ribeiro 1996).

Results obtained in this experiment highlight the potential risk caused by the presence of these species in Scots pine nurseries and in the first years after transferring them to the forest. On the basis of our preliminary results, a large-scale study involving sampling, isolation and species diversity determination of Phytophthora species in different young conifer stands and nurseries of Scots pine is warranted. Soil-infestation pathogenicity tests, as the closest experimental conditions to natural way of infection, are also required in the future to evaluate the potential of Phytophthora species to infect and damage mature Scots pine roots in field conditions. 


\section{ACKNOWLedgements}

We are grateful to IBL support (Scholarship Funds 2016) to IM and LB. European Commission (COST action TD1209) and the Ministry of the Education, Science and Technological Development, Republic of Serbia, are also acknowledged for STSM fellowship to IM and support to the project TR 37008 , respectively.

\section{References}

Abad G.Z. 2014. The Taxonomy of Phytophthora: What is done and what is needed for the correct identification and diagnostics of species in the Genus. In: 7th International Union of Forest Research Organizations, IUFRO Working Party 7-02-09 Meeting, Phytophthora in Forests and Natural Ecosystems, Esquel, Chubut. Patagonia, Argentina, November, 10-14, 2014.

Adl S.L., Simpson A.G.B., Lane C.E., Lukeš J., Bass D., Bowser S.S., Brown M.W., Burki F., Dunthorn M., Hampl V., Heiss A., Hoppenrath M., Lara E., Lee Gall L., Lynn D.H., McManus H., Mitchell E.A.D., Mozley-Stanridge S.E., Parfrey L.W., Pawlowski J., Rueckert S., Shadwick L., Schoch C.L., Smirnow A., Spiegel F.W. 2012. The revised classification of eukaryotes. The Journal of Eukaryotic Microbiology, 59 (5), 429-493.

Duda B., Orlikowski L.B., Szkuta G. 2004. Settlement of Scots pine seedlings by Phytophthora cinnamomi Rands in nurseries. Progress in Plant Protection, 44 (1), 59-63 [in Polish].

Durán A., Gryzenhout M., Slippers B., Ahumada R., Rotella A., Flores F., Wingfield B.D., Wingfield M.J. 2008. Phytophthora pinifolia sp. nov. associated with a serious needle disease of Pinus radiate in Chile. Plant Pathology, 57, 715-727. doi: 10.1111/j.1365-3059.2008.01893.x

EFSA Panel on Plant Health (PLH). 2013. Scientific Opinion on the risk to plant health posed by Dothistroma septosporum (Dorog.) M. Morelet (Mycosphaerella pini E. Rostrup, syn. Scirrhia pini) and Dothistroma pini Hulbary to the EU territory with the identification and evaluation of risk reduction options. EFSA Journal, 11 (1), 3026. doi:10.2903/j. efsa.2013.3026.
Érsek T., Man in’t Veld W.A. 2013. Phytophthora species hybrids: a novel threat to crops and natural ecosystems. In: Phytophthora: a global perspective (ed.: K. Lamour). CABI, Wallingford, 37-47.

Erwin D.C., Ribeiro O.K. 1996. Phytophthora diseases worldwide. APS Press, American Phytopathological Society, St. Paul, Minnesota, 1-592.

Hansen E.M. 2011. Phytophthora lateralis. Forest Phytophthoras, 1 (1), doi: 10.5399/osu/fp.1.1.1816.

Hansen E.M. 2012. Phytophthora pinifolia. Forest Phytophthoras, 2 (1), doi: 10.5399/osu/fp.2.1.3056.

Hong C.X., Gallegly M.E., Richardson P.A., Kong P. 2011. Phytophthora pini Leonian resurrected to distinct species status. Mycologia, 103, 351-360.

Hudler G.W. 2013. Phytophthora cactorum. Forest Phytophthoras, 3 (1), doi:10.5399/osu/fp.3.1.3396.

Jung T., Blaschke H., Neumann P. 1996. Isolation, identification and pathogenicity of Phytophthora species from declining oak stands. European Journal of Forest Pathology, 26, 253-272.

Jung T., Burgess T.I. 2009. Re-evaluation of Phytophthora citricola isolates from multiple woody hosts in Europe and North America reveals a new species, Phytophthora plurivora sp. nov. Persoonia, 22, 95-110.

Jung T., Orlikowski L., Henricot B., Abad-Campos P., Aday A.G., Aguín Casal O., Bakonyi J., Cacciola S.O., Cech T., Chavarriaga D., Corcobado T., Cravador A., Decourcelle T., Denton G., Diamandis S., Doğmuş-Lehtijärvi H.T., Franceschini A., Ginetti B., Green S., Glavendekić M., Hantula J., Hartmann G., Herrero M., Ivic D., Horta Jung M., Lilja A., Keca N., Kramarets V., Lyubenova A., Machado H., Magnano di San Lio G., Mansilla Vázquez P.J., Marçais B., Matsiakh I., Milenkovic I., Moricca S., Nagy Z.Á., Nechwatal J., Olsson C., Oszako T., Pane A., Paplomatas E.J., Pintos Varela C., Prospero S., Rial Martínez C., Rigling D., Robin C., Rytkönen A., Sánchez M.E., Sanz Ros A.V., Scanu B., Schlenzig A., Schumacher J., Slavov S., Solla A., Sousa E., Stenlid J., Talgø V., Tomic Z., Tsopelas P., Vannini A., Vettraino A.M., Wenneker M., Woodward S., Peréz-Sierra A. 2016. Widespread Phytophthora infestations in European nurseries put forest, semi-natural and horticultural ecosystems at high risk of Phytophthora diseas- 
es. Forest Pathology, 46 (2), 89-176, doi:10.1111/ efp.12239.

Jung T., Vettraino A.M., Cech T., Vannini A. 2013. The impact of invasive Phytophthora species on European forests. In: Phytophthora: a global perspective (ed.: K. Lamour). CABI, Wallingford, 146-158.

Lara E., Belbahri L. 2011. SSU rRNA reveals major trends in oomycete evolution. Fungal Diversity, 49, 93-100.

Leonian L.H. 1925. Physiological studies on the genus Phytophthora. West Virginia Agriculture Experiment Station Scientific Paper, 11, 444-498.

Małecka M., Sierota Z. 2003. Threat and risk assessment of root and butt rot disease in a stand on postagricultural land (in Polish). Sylwan, 11, 12-25.

Man in't Veld W., de Cock A.W.A.M., Summerbell R.C. 2007. Natural hybrids of resident and introduced Phytophthora species proliferating on multiple new hosts. European Journal of Plant Pathology, 117, 25-33.

Man in’t Veld W., Rosendahl K.C.H.M., Hong C. 2012. Phytophthora $\times$ serendipita $\mathrm{sp}$. nov. and $P . \times$ pelegrandis, two destructive pathogens generated by natural hybridization. Mycologia, 104 (6), 1390-1396.

Mańka K. 1998. Forest phytopathology (in Polish). PWRiL, Warszawa.

Martin F.N., Blair J.E., Coffey M.D. 2014. A combined mitochondrial and nuclear multilocus phylogeny of the genus Phytophthora. Fungal Genetics and Biology, 66, 19-32.

Milewski W. 2015. Forests in Poland 2015 (in Polish). Centrum Informacyjne Lasów Państwowych, Warsaw.

Milenković I., Keča N., Karadžić D., Nowakowska J.A., Borys M., Sikora K., Oszako T. 2012. Incidence of Phytophthora species in beech stands in Serbia. Folia Forestalia Polonica, Series A - Forestry, 54 (4), 223-232.

Moralejo E., Pérez-Sierra A.M., Álvarez L.A., Belbahri L., Lefort F., Descals E. 2009. Multiple alien Phytophthora taxa discovered on diseased ornamental plants in Spain. Plant Pathology, 58, 100-110. doi: 10.1111/j.1365-3059.2008.01930.x.

Orlikowski L.B., Duda B., Szkuta G. 2004. Phytophthora citricola on European beech and silver fir in
Polish forest nurseries. Journal of Plant Protection Research, 44 (1), 57-64.

Orlikowski L.B., Oszako T., Duda B., Szkuta G. 2004. Occurrence of Phytophthora citricola on ash (Fraxinus excelsior) in forest nurseries (in Polish). Leśne Prace Badawcze, 4, 129-136.

Orlikowski L.B., Oszako T., Szkuta G. 2006. First record of Phytophthora spp. associated with the decline of European beech stands in south-west Poland. Phytopathologia Polonica, 42, 37-46.

Orlikowski L.B., Ptaszek M., Trzewik A., Orlikowska T., Szkuta G., Meszka B., Skrzypczak C. 2012. Risk of horticultural plants by Phytophthora species (in Polish). Progress in Plant Protection, 52 (1), 92-100.

Oszako T., Orlikowski L.B. 2004. The first noting of Phytophthora citrophthora on Picea abies in a forest stand. Phytopathologia Polonica, 34, 81-85.

Oszako T., Orlikowski L.B. 2005. First data on the occurrence of Phytophthora cinnamomi on pedunculate oak in Poland (in Polish). Sylwan, 149 (10), 47-53.

Oszako T., Orlikowski L.B., Trzewik A. 2007. Menace to Polish forest nurseries by Phytophthora species (in Polish). Progress in Plant Protection, 47 (2), 224-234.

Pérez-Sierra A., Jung T. 2013. Phytophthora in woody ornamental nurseries. In: Phytophthora: a global perspective (ed.: K. Lamour). CABI, Wallingford, 166-177.

Rytkönen A. 2011. Phytophthora in Finnish nurseries. Dissertationes Forestales, 137, Helsinki University Print, Helsinki, 1-38.

Scott P.M., Burgess T.I., Hardy G.E.S.J. 2013. Globalization and Phytophthora. In: Phytophthora: a global perspective (ed.: K. Lamour). CABI, Wallingford, 226-232.

Sierota Z. 1996. Threats stands on former farmland by fungal pathogens (in Polish). Sylwan, 12, 5-15.

Stępniewska H. 2003. Occurrence of Phytophthora cactorum on tree seedlings with damping-off symptoms in some forest nurseries in south of Poland. Phytopathologia Polonica, 29, 53-67.

Stępniewska H. 2005. Phytophthora spp. on beech seedlings in selected forest nurseries southern Polish (in Polish). Leśne Prace Badawcze, supplement 1, 45-52. 
OPEN

Vannini A., Vettraino A. 2011. Phytophthora cambivora. Forest Phytophthoras, 1 (1). doi: 10.5399/osu/ fp.1.1.1811.

Załęski A., Aniśko E., Kontorowicz W. 1998. Determination of viability of seeds of trees and shrubs spro- uting method (in Polish). Dyrekcja Generalna Lasów Państwowych, Instytut Badawczy Leśnictwa, Załącznik nr 2 do „Zasad oceny nasion w Lasach Państwowych", Warszawa. 